Apidologie, 1979, 10 (1), 35-42.

\title{
GROUP EFFECT ON THE CONTENT OF 10-HYDROXYDEC-2-ENOIC ACID IN THE HEAD OF WORKER BEES
}

\author{
G. ARNOLD \\ Université René-Descartes, Laboratoire de Sociologie animale, \\ Château d'Ivoy, Ivoy-le-Pré, 18380 La Chapelle d'Angillon. \\ B. ROGER \\ Station de Recherches sur l'Abeille et les Insectes sociaux \\ I.N.R.A., 91440 Bures sur Yvette.
}

\begin{abstract}
SUMMARY
10-hydroxydec-2-enoic acid contents of isolated bees and of bees grouped by ten were measured using gaseous phase chromatography and then compared. Grouped bees were found to contain always more acid than isolated bees in similar conditions. The influence of pollen, age and season was also shown.
\end{abstract}

\section{INTRODUCTION}

Unsatured 10-hydroxydec-2-enoic (HDA) acid is a fatty acid specific of worker bees. It is produced in the bee's mandibular and hypopharyngeal glands and can be found in the food given to the larvae and particularly in royal jelly.

Its structure and localisation have been studied in a number of earlier works. A very complete survey was done by BARBIER (1968), then by PAIN and Roger (1970). The latter authors also showed the influence of the presence of brood upon the concentration of this particular acid in workers (1968) and demonstrated the existence of an annual cycle in its production (1970).

One of us (ARNOLD, 1976, 1978) has shown that the physiology of isolated bees was different from that of grouped bees : it was thus interesting to see if 10-hydroxydec2-enoic acid secretion was changed in isolated individuals. In the course of our experiments we also tried to see if and to what extent there was an influence of the age of the bees and of the quality of their food. 


\section{MATERIAL AND METHODS}

\section{1) Insects}

We used bees of the Italian subspecies Apis mellifica ligustica Spinola, hatched from brood and kept in an incubator at $33^{\circ} \mathrm{C}$. They were taken and placed in experimental conditions a few hours after birth. The experimental apiary is located at Mittainville (60 kilometers from Paris, France).

Two experiments were done : one in January, 1977 with 400 bees, the other in May, 1977 with 800 bees. In the first experiment the insects came from a reactivated hive kept at $20^{\circ} \mathrm{C}$ and permanently supplied with pollen and sugar syrup. In the second experiment they came from the same hive however since it was spring time it had been placed outdoors.

\section{2) Experimental material}

Bees were taken at random, then either isolated or grouped by ten : if isolated they were placed in glass cylinders $40 \mathrm{~mm}$ high and $40 \mathrm{~mm}$ in diameter, and if grouped by ten they were placed in similar glass cylinders $(40 \mathrm{~mm}$ in diameter) but twice as high $(80 \mathrm{~mm})$. All the cylinders were lined inside with filter paper and the screened covers were equipped with water source. All specimens were maintained in total darkness, in an incubator set at $33^{\circ} \mathrm{C}$.

\section{3) Food}

In each experiment one half of the bees were given candy only; the other half also had candy but received in addition fresh pollen which had been kept undessicated in a cold chamber at $-5^{\circ} \mathrm{C}$. Water was given ad libitum to both halves.

\section{4) Dosage of 10-hydroxydec-2-enoic acid}

It was done on 5-day old and on 10-day old bees killed by deep-freazing at $-25^{\circ} \mathrm{C}$.

The apparatus was a type CG 10 Profit ionised flame chromagas equipped with a stainless steel column on polyethylene glycol phase. 10-hydroxydec-2-enoic acid is extracted from crushing the worker heads in ether. The resulting extract is filtered, concentrated and dried, and then methylated in the presence of distillated diazomethane $\left(\mathrm{CH}_{2} \mathrm{~N}_{2}\right)$. After methylation the esters are dried then treated with predetermined amounts of hexane. Each dose of worker head extract in injected three times and compared to methylated samples of synthetic 10-hydroxydec-2-enoic acid. One dose corresponds to 50 worker heads (either from isolated or from grouped bees). Quantitative titrations of head extracts are obtained through comparing the areas of the recording peaks with that provided by zones in the respective recordings of the experimental sample and by the synthetic 10-hydroxydec-2-enoic acid methylic esters samples.

\section{RESULTS}

Detailed results of each experiment are given in Table 1. Each value is derived from the result of one titration on 50 worker bee heads and represents the mean quantity of acid per individual bee in micrograms.

Statistical analysis : we used the sign test to compare between themselves the matched series which respectively correspond to the three pairs of experimental conditions (grouping, food and age). 
TABL. 1. - Mean quantities of HDA acid per bee's head (in micrograms).

\begin{tabular}{|c|c|c|c|c|c|c|c|c|}
\hline \multirow{3}{*}{ Date } & \multicolumn{4}{|c|}{ 5-day old bees } & \multicolumn{4}{|c|}{ 10-day old bees } \\
\hline & \multicolumn{2}{|c|}{ Candy } & \multicolumn{2}{|c|}{ Candy + pollen } & \multicolumn{2}{|c|}{ Candy } & \multicolumn{2}{|c|}{ Candy + pollen } \\
\hline & I & $\mathrm{G}$ & I & $\mathrm{G}$ & I & G & I & $\mathrm{G}$ \\
\hline $\begin{array}{c}\text { January } 1977 \\
\left(\text { Experiment } n^{\circ} 1\right)\end{array}$ & $6,75^{*}$ & 27,65 & 11,55 & 28,25 & 12,85 & 20,80 & 13,05 & 52,10 \\
\hline $\begin{array}{c}\text { May } 1977 \\
\left(\text { Experiment } n^{\circ} \text { 2) }\right.\end{array}$ & $\begin{array}{r}13,20 \\
9,50\end{array}$ & $\begin{array}{l}11,50 \\
12,20\end{array}$ & $\begin{array}{l}19,70 \\
14,25\end{array}$ & $\begin{array}{l}48,25 \\
40,00\end{array}$ & $\begin{array}{c}18,60 \\
-\end{array}$ & $\begin{array}{l}27,10 \\
38,90\end{array}$ & $\begin{array}{l}33,05 \\
33,60\end{array}$ & $\begin{array}{l}43,45 \\
56,20\end{array}$ \\
\hline (Mean over 100 bees) & 11,35 & 11,85 & 16,95 & 44,10 & 18,60 & 33,30 & 33,30 & 49,80 \\
\hline
\end{tabular}

- Each number represents the mean over 50 bees.

$\mathrm{I}=$ isolated bees.

$\mathbf{G}=$ grouped bees (by 10 ).

\section{a) Influence of grouping :}

The average 10-hydroxydec-2-enoic acid content in grouped worker bees is significantly higher than in isolated bees in similar conditions $(p=0,004)$. Cumulative results of both experiments appear in figure 1 . We can see that depending upon the type of food and upon age, the grouped insects contain from $56 \%$ to $156 \%$ more 10 -hydroxydec-2-enoic acid than the isolated ones.

\section{b) Influence of food:}

The worker bees which are given pollen contain, on the average, significantly more 10-hydroxydec-2-enoic acid than those which are given only candy $(p=0,004)$. One can see in figure 1 that the mean 10-hydroxydec-2-enoic acid content in lot A bees (5-day old, isolated, fed with candy only) is much less than in bees from lot $\mathbf{A}^{\prime}$ (5-day old, isolated, fed with candy + pollen) : the difference is $55 \%$. The tendency is stronger still in bees from lots B and B' (grouped insects, respectively without and with pollen) as the difference reaches $125 \%$.

\section{c) Influence of age :}

10-day old worker bees contain, on the average, significantly more 10hydroxydec-2-enoic acid than 5-day old worker bees in identical conditions $(p=0,035)$. We can see in figure 1 that there is a $30 \%$ difference in the 10 hydroxydec-2-enoic acid contents between lots $\mathrm{B}^{\prime}$ and $\mathrm{D}^{\prime}$ (grouped, with pollen, respectively 5-day and 10-day old); the difference is stronger still (75\%) between lots . $\mathrm{A}^{\prime}$ and $\mathrm{C}^{\prime}$ (isolated, with pollen, respectively 5-day and 10-day old). 


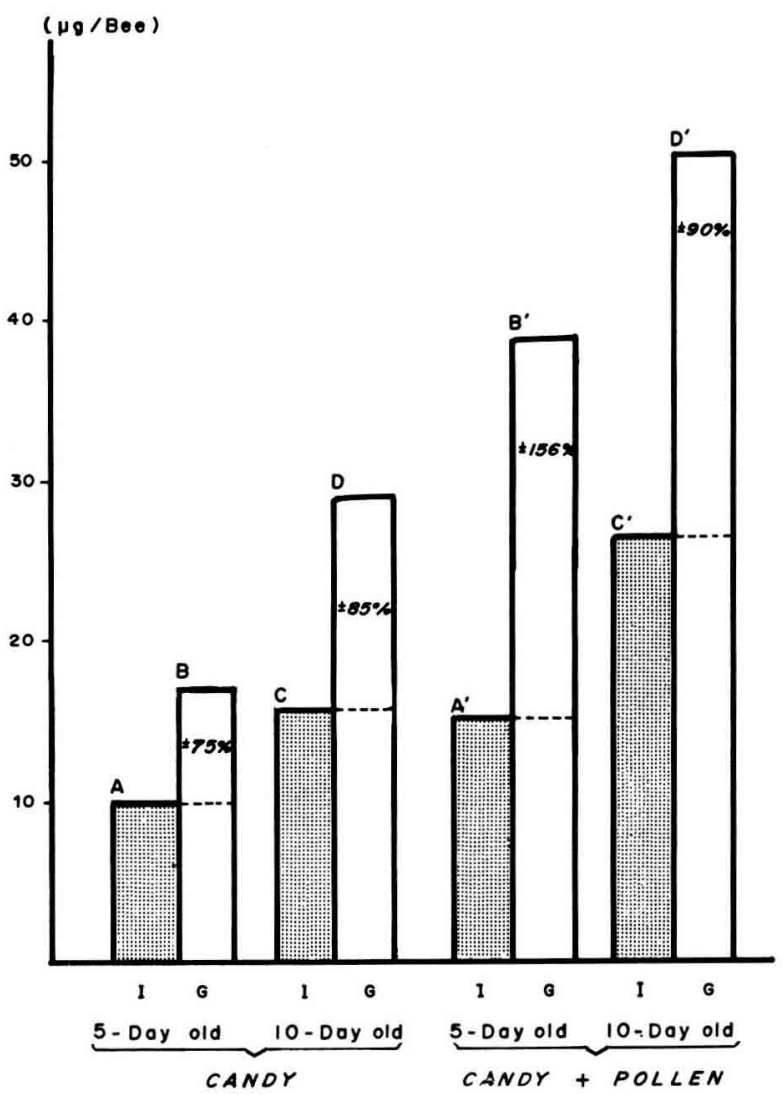

FIG. 1. - Importance of group effect and pollen in HDA acid contents in the heads of worker bees.

The amount of 10-hydroxydec-2-enoic acid which has accumulated in the bees during the first five days is larger than that accumulated from the 6th to the 10th day (see figure 2). Thus the difference between the groups is established during the first five days. In the following days the amount of accumulated acid is the same in all groups, except the case of isolated bees fed with candy only, where it is lower.

\section{DISCUSSION}

Our results confirm the previous observation that important physiological differences exist between isolated bees and grouped bees. Indeed, one of us has shown that the organs of isolated bees are generally less developed than those of grouped bees (ARNOLD, 1976), that their life is shorter (ARNOLD, 1978), their weight is less and they consume less food (ARNOLD, in press). 


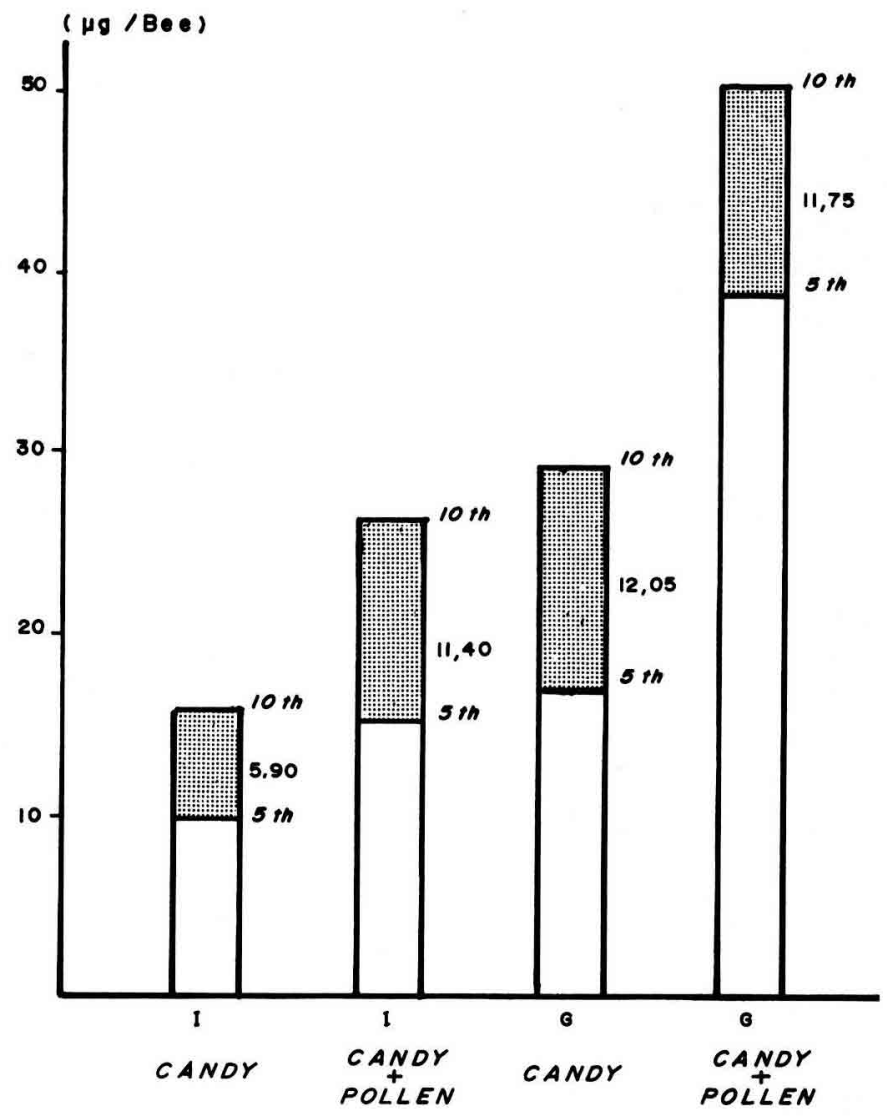

FIG. 2. - Accumulation of HDA acid as a function of the worker bees' age.

These previous results and those obtained in the present study suggest the hypothesis that the lesser 10-hydroxydec-2-enoic acid content in isolated bees is due to the lack of sensory stimuli from congeners on one hand, and to a lesser food consumption on the other hand.

It is not possible as yet to know exactly the relative importance of the two factors in this group effect on 10-hydroxydec-2-enoic acid contents. Our results clearly show however that the influence of food is important, in particular since pollen deprived bees always contain less 10-hydroxydec-2-enoic acid. The importance of pollen in the elaboration of this substance was never mentioned before, despite the fact that its role in the development of the cephalic glands of the bees has been known for quite some time (Maurizio, 1954).

10-day old bees always contain more 10-hydroxydec-2-enoic acid than 5-day old ones. We showed however that the difference between the groups builds up during the first five days, then maintains itself in the following days. The importance of the first 
five days in the physiology of bees was already pointed out by several authors, and in particular with regard to food transfers between bees (Pershad, 1966 - Douault and al., 1975).

In the present study we measured the accumulation of 10-hydroxydec-2-enoic acid without being able to take into account its possible degradation and distribution among grouped bees. In isolated bees however the latter effect is of course ruled out.

Also, our work was done with confined queenless bees without any brood to rear, whereas in a queenright colony with brood these bees would have been nurse bees and would consequently have had a lesser 10-hydroxydec-2-enoic acid content as BOCH and Shearer (1967) and Roger and Pain (1968) have shown.

Our results thus confirm the existence of variations in 10-hydroxydec-2-enoic acid content within different experimental conditions. PAIN and Roger (1970) already pointed out the influence of season in this respect; we showed here the importance of other factors such as grouping, presence of pollen in food and age. Moreover, we observed as well a seasonal variation : the values obtained in May are higher than those obtained in January with one exception. Besides, the maximum quantities of 10hydroxydec-2-enoic acid in our experiments ( $56 \mu \mathrm{g}$ per bee) are in harmony with those mentioned by PAIN and ROGER ( $65 \mu \mathrm{g}$ per bee).

\title{
CONCLUSIONS
}

This work shows that the physiological differences between isolated and grouped bees observed in previous studies also exist as concerns the production of 10hydroxydec-2-enoic acid. Grouped bees always contain more acid than isolated bees. The influence of pollen in the metabolism of this substance, and the existence of variations of age and season are also evident.

We conclude that the group effect appears to play a major part in 10-hydroxydec2-enoic acid content, but that this effect is closely linked to food, age and season.

Received in October 1978

\begin{abstract}
¡ RÉSUMÉ
INFLUENCE DE L'EFFET DE GROUPE SUR LA TENEUR EN ACIDE HYDROXY-10 DÉCĖNE-2 OIQUE DE TETES D'OUVRIËRES D'ABEILLES
\end{abstract}

Ce travail analyse par la chromatographie en phase gazeuse la teneur en acide hydroxy-10-décène-2 oïque des têtes d'abeilles isolées et d'abeilles groupées par dix.

Nous montrons (Fig. 1):

a) Influence du groupement : la teneur moyenne en acide hydroxy-10 décène-2 oïque des ouvrières groupées est toujours supérieure à celle des abeilles isolées. En fonction des conditions expérimentales les abeilles groupées contiennent de 75 à $156 \%$ d'acide hydroxy-10 décène- 2 oïque de plus que les isolées. 
b) Influence du type de nourriture : les ouvrières recevant du pollen contiennent en moyenne toujours plus (de 55 à $125 \%$ ) d'acide hydroxy-10 décène- 2 oïque que celles qui n'en ont pas reçu.

c) Influence de l'âge : les ouvrières âgées de 10 jours contiennent en moyenne toujours plus d'acide hydroxy-10 décène- 2 oïque que les abeilles âgées de 5 jours, placées dans des conditions identiques.

Nous avons mesuré aussi l'accumulation de l'acide hydroxy-10 décène- 2 oïque dans les têtes des ouvrières (fig. 2) : c'est au cours des cinq premiers jours que l'ouvrière accumule le plus d'acide. Ensuite la quantité d'acide accumulée s'avère constante d'un groupe à l'autre.

L'effet de groupe parait avoir un rôle prépondérant sur la teneur en acide hydroxy-10 décène-2 oïque des ouvrières, mais étroitement lié à la nourriture, à l'âge des abeilles et à la saison.

\section{ZUSAMMENFASSUNG}

DER EINFLUSS DES GRUPPENEFFEKTS AUF DEN GEHALT AN

10-HYDROXY-2-DECENSÄURE IN DEN KÖPFEN DER ARBEITSBIENEN

In dieser Arbeit wird mittels Gaschromatographie der Gehalt an 10-Hydroxy-2-Decensäure (HDA) in den Köpfen von Arbeiterinnen untersucht, die entweder einzeln oder in Gruppen von zehn gehalten wurden.

Wir konnten nachweisen (Abb. 1) :

a) Einen Einfluss der Haltung in Gruppen : Der mittlere Gehalt an HDA ist bei Arbeiterinnen aus Gruppen immer höher als bei einzeln gehaltenen Bienen. Unter den Bedingungen des Experiments enthielten die Bienen aus Gruppen um 75-156\% mehr HDA als isolierte Bienen.

b) Einen Einfluss der Ernährung : Arbeiterinnen, die mit Pollen gefüttert wurden, hatten im Mittel immer mehr (um 55-125\%) HDA als Bienen, die keinen Pollen erhalten hatten.

c) Einen Einfluss des Alters : Im Alter von zehn Tagen entwickelten die Arbeiterinnen unter gleichen sonstigen Bedingungen im Mittel immer mehr HDA als fünf Tage alte Arbeiterinnen.

Ausserdem haben wir die Speicherung von HDA in den Köpfen der Arbeiterinnen untersucht (Abb. 2) :

Die Bienen speichern die grössten HDA-Mengen in ihren ersten fünf Lebenstagen. Später werden bei allen Gruppen gleichgrosse Mengen der Säure gespeichert.

Der Gruppeneffekt scheint auf den Gehalt der Arbeiterinnen an HDA einen überragenden Einfluss zu haben, aber er hängt auch stark von der Ernährung, dem Alter der Bienen und der Saison ab.

\section{REFERENCES}

ArNold G., 1976. - Mécanismes mis en œuvre dans l'effet de groupe chez l'abeille. C. R. Acad. Sc. D, 283, 1433-1435.

ARNold G., 1978. - Les variations annuelles dans l'effet de groupe chez l'abeille et l'origine de la mort précoce des isolées. Insectes Soc., 25 (1), 39-51.

ARNold G., 1979. - Isolation, and its influence upon the weight development and food intake of honeybees. J. apic. Res. (in press).

BARBIER M., 1968. - Biochimie de l'abeille. in Traité de Biologie de l'abeille vol. 1, 378-409. Ed. Masson. 
Boch R., ShEARer D. A., 1967. - 2-Heptanone and 10-Hydroxy-Trans-Dec-2-Enoic Acid in the Mandibular Glands of Worker Honey Bees of different ages. Z. vergleich. Physiol. 54, 1-11.

Douault Ph., Roger B., Pain J., 1975. - Mise en évidence, au moyen d'un radio-isotope, d'une variation saisonnière dans les transferts de nourriture entre ouvrières d'abeilles. C. R. Acad. Sci. D, 280, 23492352.

MAURIzio A., 1954. - Pollenernährung und Lebensvorgänge bei der Honigbiene. Landw. Jb. Schweiz, 68 (2), 115-182.

Pain J., Roger B., 1970. - Variation annuelle de l'acide hydroxy-10 décène-2 oïque dans les têtes d'abeilles. Apidologie 1, 29-54.

Pershad S. B., 1966. - L'influence de l'âge sur les échanges de nourriture entre les ouvrières d'abeilles. Insectes Soc. 13, 323-328.

Roger B., PAIN J., 1968. - Le couvain, facteur déterminant de la teneur en acide hydroxy-10 décène-2 oïque de la tête des ouvrières d'abeilles. C. R. Acad. Sci. D, 266, 2267-2269. 